\title{
Analisis Pengaruh Aglomerasi Industi Terhadap Pertumbuhan Ekonomi dalam Pelaksanaannya di Beberapa Wilayah Indonesia
}

\author{
Barli Novirin \\ Universitas Negeri Malang \\ barli.novirin.2004328@students.um.ac.id
}

Received:

March 29, 2021

1st Revision:

August 4, 2021

Published:

August 19, 2021

\begin{abstract}
In general, economic development in some regions in Indonesia has been increased, we can observe that from several things: The rate of population and product growth per capita, increased productivity, a high rate of structural change, urbanization, and the occurrence of a growing flow of capital goods. However, not all of the numbers of economic increases occur evenly in each region, there are still many regions in Indonesia that have not met the criteria as areas with good economic development, one of the causes is about the concentration of economic activity only in one area, these activities invent a phenomenon that called agglomeration industry. This study aims to identify the phenomenon of Industrial Agglomeration and its implementation and its effects on the economy that occurs in several regions in Indonesia, besides this research will also look at the advantages and disadvantages of Industrial Agglomeration it self, where this can be used as a sign of economic development in Indonesia. an area or not. The objectives of this research are: (1). The creation of industrial downstreaming, (2). Facilitating technology transfer from the Upstream Industry, and (3). Carry out periodic Industrial Agglomeration assessments.
\end{abstract}

Keywords: Advantages, Disadvantages, Agglomeration, Industry 
serta (3). Melaksanakan penilaian Aglomerasi Industri secara berkala.

Kata Kunci: Kelebihan, Kekurangan, Aglomerasi, Industri.

\section{PENDAHULUAN}

Pertumbuhan ekonomi dari adanya arus urbanisasi bisa berdampak positif dan juga dapat menjadi permasalahan bagi suatu wilayah, dengan adanya arus urbanisasi tersebut, kondisi suatu wilayah akan menimbulkan daerah-daerah kumuh, dapat juga menciptakan peningkatan pengangguran dikarenakan terjadi penumpukan tenaga kerja yang tidak terlatih, dimana akan menimbulkan sektor-sektor yang tidak tertata dengan baik sehingga dapat menambah permasalahan sosial di suatu wilayah. Dengan adanya arus urbanisasi jika terjadi secara berulang akan menciptakan big cities atau mega cities dan terjadi aglomerasi industri yang akan menciptakan masalah baru diantaranya kemacetan, polusi, daerah kumuh, pencemaran lingkungan, dan lain sebagainya, bersumber dari realitas ini pembangunan suatu wilayah harus memperhatikan dan mempertimbangkan permasalahan ini.

Pembangunan suatu wilayah dengan adanya aglomerasi industri di berbagai sektor industri memiliki ciri khas dari masing-masing sektor industri tersebut, misalnya industri manufaktur (manufacturing industry) biasanya berlokasi di dalam serta di sekitar perkotaan. Di kawasan aglomerasi, wilayah Industri dan pertanian saling bersampingan, saling bersaing dalam perebutan tanah atau lahan di sekitar pusat-pusat perkotaan yang akhirnya membiaskan perbedaan baku antara kota dan pedesaan. Industri-industri biasanya beraglomerasi di wilayah-wilayah yang mana wilayah tersebut berpotensi dan wilayah tersebut memiliki keunggulan masing-masing yang dibutuhkan industriindustri, mereka memanfaatkan lokasi industry/perusahaan yang saling berdekatan. dikarenakan terjadinya aglomerasi tersebut umumnya memberikan keunggulan diantaranya yaitu, (a). Dari adanya produktivitas, (b). Upah yang lebih tinggi sehingga menarik investor baru, (c). Teknologi yang terbarukan, (d). Sumber daya manusia yang unggul.

Dalam sektor perekonomian jangka panjang bank dunia membagi negara maju dan negara sedang berkembang (NSB) yaitu: "(1). Negara maju yang memiliki penghasilan tinggi dan mengandalkan perekonomian dari sektor industry, (2). Negara sedang berkembang (NSB) yang berpenghasilan menengah dan sektor industri dalam bidang perekonomian sedang dalam tahap berkembang, (3). Negara dunia ketiga yang berpenghasilan rendah dan tidak memiliki sektor industri yang dapat di andalkan dalam perekonomian, (4). Negara-negara pengekspor minyak yang dikelompokan secara khusus, tidak dimasukan dalam tiga kelompok di atas. Ini dikarenakan negaranegara tersebut memiliki pertumbuhan ekonomi yang sangat cepat karena mengandalkan sektor pertambangan minyak bumi dan gas alam yang harganya terus meningkat. (Mulyani, 2017). Bersumber dari realitas ini, kita dapat melihat bahwa, dewasa ini perkembangan perekonomian pada sektor industri di suatu negara, memiliki andil yang sangat berarti.

Glaeser, et. al. (1992), memiliki sebuah terminology yang bernama "Dynamic Externalities" yang memaparkan "bagaimana sektor industri bisa mendapatkan dampak atau keuntungan dari terjadiannya ekonomi eksternal". Lalu terminology tersebut, "Dynamic Externalities" terdiri dari tiga bagian, yaitu: (1). Eksternalitas Marshall-Arrow-Romer (MAR), (2). Eksternalitas Jacobs, dan, (3). Eksternalitas Porter. Ketiga teori ini kemudian diketahui sebagai spesialisasi, diversitas dan kompetisi. Teori MAR tentang spiollovers dalam industri menyatakan bahwa perusahaan diuntungkan dengan lokasi dan proksimitas fisik dengan adanya pertukaran informasi dan pengetahuan serta 
pengurangan biaya tenaga kerja. Ini dikarenakan perpindahan informasi dan pengalaman dari satu industri ke industri lain dalam satu wilayah tidak disertai dengan kompensasi yang layak.

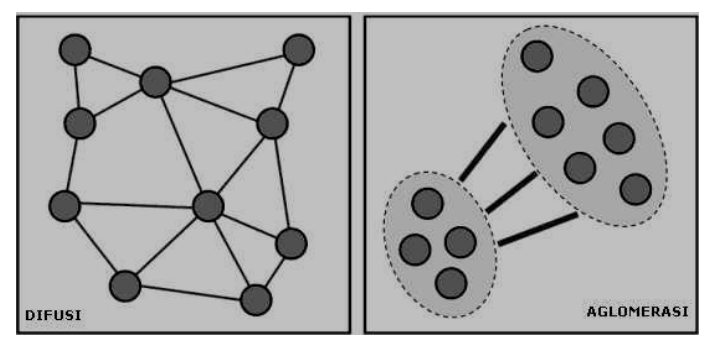

Gambar 1 Perbedaan Difusi dan Aglomerasi

Gambar 1 menunjukan perbedaan dari difusi dan aglomerasi, difusi merupakan perluasan daerah sedangkan aglomerasi adalah terpusatnya daerah, istilah aglomerasi muncul berawal dari teori Marshall (1980), tentang Ekonomi Aglomerasi (Agglomeration Economies) atau dalam istilah Marshall disebut sebagai industri yang terlokalisir (Localized Industries). Agglomeration Economies atau Localized Industries muncul ketika sebuah industri memilih lokasi untuk kegiatan produksinya yang memungkinkan dapat berlangsung dalam jangka panjang sehingga masyarakat akan banyak memperoleh keuntungan apabila mendirikan usaha disekitar lokasi tersebut. (Saleh \& Warlina, 2017)

Hoover (1948) mengklasifikasikan Aglomerasi menjadi 3 jenis, yaitu: (1). Large Scale Economies: Keuntungan yang diperoleh industri karena membesarnya skala produksi industri tersebut dalam satu lokasi, (2). Locatization Economies: Keuntungan yang diperoleh semua industri yang sama dalam suatu lokasi. Keuntungan ini timbul kerena kegiatan produksi saling berkaitan dan terkonsentrasi pada suatu tempat, maka ongkos angkut bahan baku dan bahan jadi akan berkurang, produksi akan lebih besar karena persediaan bahan baku, tenaga terampil, dan pasar terjamin, (3). Urbanization Economies: Keuntungan bagi semua industri pada suatu lokasi yang sama sebagai dampak dari membesarnya skala ekonomi (penduduk, pendapatan, output atau kemakmuran) dari lokasi tersebut. (Capello \& Nijkamp, 2009)

(Sjafrizal, 2014) mengemukakan bahwa teori lokasi dibagi menjadi tiga bagian adalah:

1. Bid Rent Theories, yaitu kelompok teori lokasi yang mendasarkan analisis pemilihan lokasi kegiatan ekonomi pada kemampuan membayar sewa tanah (bid rent) yang berbeda dengan harga pasar sewa tanah (land rent). Berdasarkan hal ini, lokasi kegiatan ekonomi ditentukan oleh nilai bid rent yang tinggi yang dapat dibayarkan oleh pengguna tanah.

2. Least Cost Theories yaitu kelompok teori lokasi yang mendasarkan analisisnya pada pemilihan lokasi kegiatan industri yang didasarkan pada prinsip biaya minimum (least cost). Dalam hal ini, lokasi yang terbaik (optimal) adalah pada tempat dimana biaya produksi dan ongkos angkut paling kecil.

3. Market Area Theories yaitu kelompok teori lokasi yang mendasarkan analisis pemilihan lokasinya kegiatan ekonomi pada prinsip luas pasar (market area) terbesar yang dapat dikuasai 
perusahaan. Luas pasar tersebut adalah mulai dari lokasi pabrik sampai ke lokasi konsumen yang membeli produk perusahaan bersangkutan.

Aglomerasi ini pada umumnya berdampak pada pertumbuhan industri yang juga membuat kekuatan dispersi, seperti naiknya upah tenaga kerja yang unggul dan kasar juga naiknya gaji para manajer yang membuat para pelaku industri mulai memilih lokasi diluar pusat wilayah, pertumbuhan ini juga membuat lahan tahan menjadi naik (Bid rent theories) dikarenakan jumlahnya yang tidak banyak.

Dengan adanya aglomerasi industri yang memiliki sentralisasi (central place) kegiatan perekonomian dari hulu ke hilir, sentralnya pusat pertumbuhan (growth pole) yang memiliki ciri-ciri sebagai berikut: "(a). Barang dan jasa yang Homogen, (b). Persaingan sempurna antar industriindustri di setiap wilayah, (c). Biaya transport bersaing, (d). Aliran satu arah, (e). Sentralisasi, (f). Aksesibilitas vertical, (f). size dependency. Memiliki perbedaan dengan sistem jaringan (network place) yang memiliki ciri sebagai berikut:, “(a). Memiliki kecenderungan maneju fleksibilitas serta komplementaritas, (b). memiliki aliran dua arah, (c). Persaingan tidak sempurna dengan diskriminasi harga, (d). Aksebilitas horizontal, (e). Nodalitas. Kedua sistem tersebut baik sentral (central place) Maupun sistem jaringan (network place) pada suatu wilayah memiliki kekuatan dan kelemahan masingmasing.

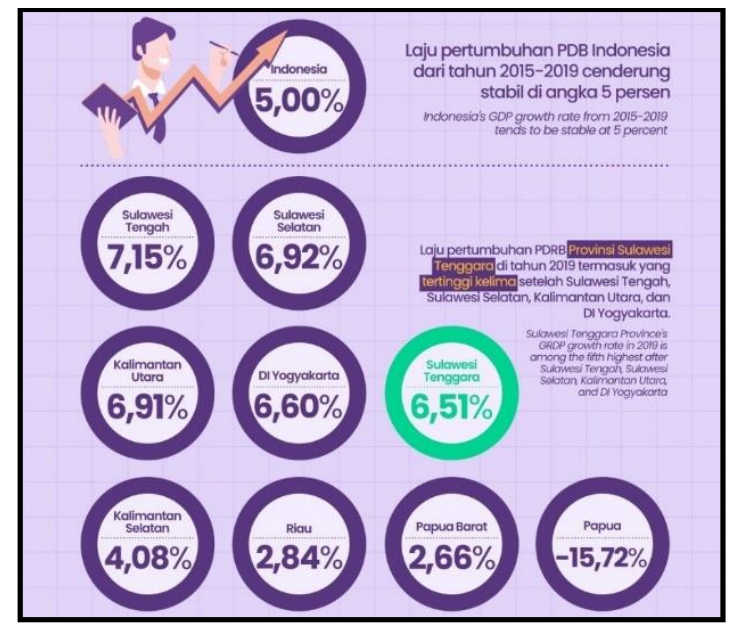

Sumber: BPS

Gambar 2. Laju pertumbuahan PDRB beberapa Provisi di Indonesia 2019

Dari Gambar 2 bisa kita lihat bahwa laju pertumbuhan PDB di Indonesia dari tahun 20152019 cenderung stabil di angka 5 persen, laju pertumbuhan PDRB dibeberapa provinsi memiliki perbedaan di tiap provinsi, Perbedaan pertumbuhan ekonomi yang terjadi ini dapat disebabkan oleh beberapa faktor, salah satunya adalah perbedaan endowment, sumber daya, merupakan komponen penting dalam mendorong peningkatan produktifitas dalam proses produksi sehingga terjadi kenaikan pertumbuhan ekonomi. (Kusumasari \& Kartiasih, 2017) 
Pertumbuhan perekonomian baik dikota maupun di perdesaan memiliki disparitas tersendiri, khususnya desa harus didorong agar dapat mempunyai ciri khas, namun juga harus memiliki nuansa perdesaan, namun demikian, masyarakat daerah masih dapat dikatagorikan "orang kota" meskipun kenyataannya masih tinggal di daerah perdesaan. Kualitas SDM dan insfrasturktur yang tidak merata di suatu daerah, diperlukan peran pemerintah agar bisa membuat arah kebijakan yang sesuai untuk mengatasi disparitas serta mendorong pertumbuhan suatu wilayah.

\section{METODE PENELITIAN}

Dalam pembuatan jurnal penelitian ini mengenai kelebihan dan kekurangan aglomerasi dalam pelaksanaannya di beberapa wilayah Indonesia menggunakan data sekunder. Sumber data sekunder merupakan sumber data penelitian yang diperoleh melalui media perantara atau secara tidak langsung yang berupa buku, catatan, jurnal, bukti yang telah ada, atau arsip baik yang dipublikasikan maupun yang tidak dipublikasikan secara umum, dengan kata lain, penelitian membutuhkan pengumpulan data dengan cara berkunjung ke perpustakaan, pusat kajian, pusat arsip atau membaca banyak buku yang berhubungan dengan penelitian. Pengertian lain mengenai sumber sekunder yaitu sumber yang tidak langsung memberikan data kepada pengumpul data, misalnya lewat orang lain atau lewat dokumen. Dokumen yang dihasilkan bisa melalui Data BPS dan buku literatur yang telah terekomendasi oleh beberapa peneliti yang memiliki data terstruktur serta pengambilan data dari website hasil yang efektif dalam penentuan kebijakan. (Sugiyono, 2009)

Dari berbagai literatur dan situs online akan dibuat sebuah rekomendasi yang sesuai yang dapat digunakan masyarakat dan pemerintah menggunakan hasil dari penelitian ini untuk dikaji lebih dalam mengenai kelebihan dan kekurangan sehingga dapat dijadikan suatu solusi implementasi nyata dilapangan.

\section{HASIL DAN PEMBAHASAN}

Fenomena aglomerasi industri beserta pengaruhnya terhadap perekonomian ekonomi yang diimplementasikan di beberapa wilayah di Indonesia, kelebihan serta kekurangan aglomerasi industri yang terjalin di beberapa wilayah di Indonesia. Berikut ini adalah beberapa kajian yang membahas aglomerasi industri. Penelitian terdahulu yang membahas aglomerasi industri yang dilakukan oleh (Putra, 2015) yang dalam penelitiannya mengkaji aglomerasi industri Kawasan Ekonomi Khusus (KEK) Sei Mangkei terhadap peningkatan efisiensi industri wilayah dan sekitarnya menunjukan bahwa aglomerasi secara spread effect menghasilkan keuntungan aglomerasi yang menghasilkan tiga keuntungan sebagai berikut: (1). Keuntungan skala besar (scale ecomonies) yang terjadi baik karena baik bahan baku yang tersedia dan akan menciptakan pasar di lokasi tersebut, (2). Keuntungan lokalisasi (localitation economies) dimana ongkos angkut yang awalnya masih secara sendiri dikawasan sekitar akan menjadi lebih murah karena digunakan secara bersama-sama, (3). Keuntugnan karena penggunaan fasilitas secara bersama (urbanization economies) seperti listrik, gudang, armada angkutan, air yang menajadi pemusatan dari aglomerasi. Adapun sebab akibat dari produksinya KEK Sei Mangkei memberi dampak negatif diantaranya seperti “(a). Adanya limbah produksi, (b). Terjadinya pencemaran lingkungan, (c). Kebisingan atau suara yang sangat mengganggu pendengaran, maupun gangguan lainnya”. 
Penelitian (Purbatin \& Soenjoto, 2020) membahas mengenai aglomerasi industri yang dalam penelitiannya mengkaji dampak aglomerasi industri dan perekonomian di jawa timur (studi kasus 5 daerah aglomerasi di jawa timur tahun 2016-2017) 5 daerah aglomerasi industri di jawa timur dengan skala besar adalah: Pasuruan, Sidoarjo, Gresik, Mojokerto dan Lamongan hasil dari kajian tersebut yaitu peneliti menguraikan dampak dari aglomerasi industri di jawa timur yaitu, (1). Dampak ekonomi: peningkatan produksi dan pendapatan yang memberi PDB pada masing-masing daerah aglomerasi, pengurangan penganguran dengan adanya penyerapan tenaga kerja yang melalui proses rekrutmen, pengaruh langsung dirasakan oleh masyarakat sekitar lokasi dengan tumbuhnya gerakan ekonomi penunjang seperti kos-kosan, warung dll, (2). Terjadinya Dampak lingkungan: Flora dan fauna dapat rusak karena adanya polusi tanah dan air, makin banyaknya pendatang sehingga bertambahnya kepadatan penduduk, keindahan lingkungan alam dapat berubah dikarenakan minimnya lahan hijau, (3). Dampak pemanfaatan: kesehatan, keamanan, dan kenyamanan terhadap pejalan kaki melalui lalu lintas, terhadap social budaya yaitu terjadi karena terpecahnya atau terganggunya masyarakat atau kelompok yang ada.

(Zuliastri et al., 2018) membahas mengenai aglomerasi industri dalam penelitiannya yaitu "faktor yang mempengaruhi aglomerasi industri unggulan daerah dan daya saing industri daerah" menyebutkan bahwa keuntungan yang diperoleh dari aglomerasi industri yaitu adanya daya saing dan aglomerasi industri memiliki hubungan dua arah positif, industri yang teraglomerasi akan memperoleh penghematan berupa penurunan biaya-biaya sehingga dapat meningkatkan daya saing. Begitu juga, semakin berdaya saing suatu industri maka semakin terdorong untuk beraglomerasi di suatu lokasi dengan tujuan untuk lebih meningkatkan efisiensi. Keragaman industri dan tingkat upah berpengaruh negatif terhadap aglomerasi dan kurangnya pemerataan pembangunan jalan.

Kajian dari (Saleh \& Warlina, 2017) membahas mengenai Aglomerasi Industri di Cikarang Kabupaten Bekasi. Kajian tersebut menghasilkan bahwa kegiatan industri di kota Cikarang menjadi fenomena menarik dari adanya aglomerasi industri yang terjadi di beberapa wilayah perkotaan Cikarang. Karateristik wilayah aglomerasi tersebut dilihat berdasarkan jumlah industri, tingkat kepadatan tenaga kerja, serta luasnya wilayah. Aglomerasi industri yang terjadi di wilayah tersebut menghasilkan beberapa keuntungan diantaranya, adanya peningkatan jumlah para pekerja, jenis industri, tingkat kepadatan industri serta jaringan jalan mempermudahnya akses transportasi.

Bisa kita lihat bahwa kajian (Wulandari et al., 2019) yang membahas Aglomerasi industri pengolahan di wilayah Kabupaten Jember dengan sub sektor Industri makanan, minuman dan tembakau. Dalam penelitian aglomerasi industri menyatakan bahwa aglomerasi yang terkonsentrasi secara spasial menghasilkan penghematan ekonomi serta penghematan urbanisasi, penghematan tersebut dapat diartikan secara teoritis yaitu agglomeration economics. Menjadikan wilayah tersebut berkembang pertumbuhan ekonomi secara keseluruhan. Hal tersebut terjadi dikarenakan adanya ekternalitas yaitu aturan advantage dan knowlage spillover dan tenaga kerja yang terspesialisasi.

Jika dikaji lebih mendalam beberapa penelitian menunjukkan bahwa aglomerasi industri di beberapa daerah di Indonesia memiliki kesamaan sesuai teori Hoover (1948) aglomerasi industri yang terjadi menimbulkan tiga keuntungan yaitu: scale economies, locatization economies, Urbanization economies. 
Hadirnya masyarakat dikawasan industri dapat meningkatkan peluang usaha baru atau mengembangkan inovasi dan kreatifitas. Infrastruktur yang dibangun dikarenakan Aglomerasi industri, dapat meningkatkan efisiensi dan efektifitas, serta kelengkapan akses transportasi peningkatan kelengkapan tersebut membuat peran aglomerasi menjadi signifikan bagi pertumbuhan pembangunan tidak hanya di sektor ekonomi namun juga disektor lainnya, misalnya sektor Sosial, Budaya dan lain sebagainya. Peran dari 3 pilar besar dari daerah yaitu Pihak Pemerintah (Eksekutif dan Legislatif), pihak swasta dan masyarakat (citizen) harus dilakukan dengan harmonis, kerjasama yang baik dari 3 pilar tersebut sangat diperlukan untuk memberikan sumbangsih agar mewujudkan tujuan utama pemerintah yaitu memberikan pelayanan dan infrastruktur yang baik kepada Masyarakat. Terbukanya Akses tersebut, akan secara otomatis mendorong kedatangan investor yang diimbangi dengan dipermudahnya Birokrasi serta Administrasi sehingga hal tersebut dapat mewujudkan pertumbuhan Ekonomi didaerah sekitar.

Wilayah atau daerah yang mengalami Aglomerasi Industri akan menjadi lokasi yang strategis dikarenakan kegiatan ekonomi yang timbul di dalamnya. Adapun lokasi yang strategis disini dapat dilihat dari beberapa faktor yang menyebabkan antara lain: "(a). Biaya angkutan. (b). Terciptanya disparitas gaji para pekerja, (c). Terpusatnya demand, (d). Adanya rivalitas antar industry”.

Tolak ukur penghematan aglomerasi industri dalam skala ekonomis serta cakupannya, tergantung dari seberapa efisien aktifitas ekonomi di sekitar wilayah aglomerasi, inipun dapat dilihat dari terciptanya jaringan usaha-usaha yang saling terkait dan pasar tenaga kerja yang terdapat di kluster aglomerasi industri. Klaster-klaster wirausaha yang tercipta dari aglomerasi industri ini, dapat menghasilkan bauran klaster industry yang semakin baik, aglomerasi dapat meningkatkan kualitas sumber daya manusia dikarenakan adanya migrasi tenaga kerja, dampaknya isu pengangguran yang menjadi isu utama bisa selesai dengan jiwa intrepenership. tentunya peran pemerintah dalam menentukan kebijakan kurikulum pendidikan untuk menjadikan masyarakat menjadi sumber daya unggul yang mampu meningkatkan inpendensi memanfaatkan bauran aglomerasi tersebut.

Aglomerasi industri yang terjadi di beberapa wilayah Indonesia ini dengan Least Cost Theories mendapatkan hasil aglomerasi yang biayanya rendah dikarenakan pemusatan yang terjadi. Lalu, melalui dengan Market Area Theories mendapatkan hasil efisiensi serta peningkatan area pembauran dan market, serta terciptanya aglomerasi industri sebagai lokasi strategis, lalu dengan Bid Rent Theories mendapatkan hasil meningkatnya harga lahan diwilayah aglomerasi industri tersebut, dikarenakan harga permintaan berubah ketika jarak dengan Central Business District meningkat. Sehingga dalam menentukan Aglomerasi Industri sebagai pusat pertumbuhan ekonomi harus memperhatikan berbagai keuntungan lokasi yang dipilih, tentunya harus melalui uji kelayakan yang sangat jelas, dimana daerah tersebut harus memiliki potensi agar dapat ditingkatkan serta adanya input dan output dari industri di berbagai sektor dan kegiatan potensial yang dapat ditingkatkan pada pertumbuhan terpusat, sehingga terciptanya hilirisasi industri dan sustainable development.

Aglomerasi tidak hanya memberikan dampak kepada daerah-daerah yang mana kegiatan perekonomian itu terjadi. Namun juga, terhadap daerah-daerah disekitarnya. Pengaruh tersebut memang terjadi, baik secara langsung maupun tidak langsung, oleh karena itu juga memunculkan dampak berupa dampak positif dan dampak negatif. Dampak positif yang didapatkan yaitu membawa keuntungan bagi segala sektor yang terlibat didalamnya sehingga mendorong terciptanya 
pertumbuhan ekonomi. Selain dampak positif kita juga tidak dapat mengesampingkan adanya dampak negatif yaitu menimbulkan beban biaya yang besar, kerugian secara sosial dan disparitas di daerah.

Akibat terjadinya aglomerasi industri memang akan berimbas terhadap masyarakat dan lingkungan diantaranya (Polusi, Pencemaran lingkungan, limbah produksi, kemacetan, over-population, alih fungsi lahan, kesehatan, dan sebagainya) oleh karena itu pentingnya peran pemerintah, swasta dan masyarakat untuk dapat meminimalisir sebab akibat dari aglomerasi industri.

\section{KESIMPULAN DAN SARAN}

Dari hasil dan pembahasan yang dilakukan, dapat ditarik kesimpulan bahwa aglomerasi industri memiliki Advantages, yaitu:

1. Lapangan Pekerjaan

Pertumbuhan ekonomi akibat aglomerasi industri berakibat bertambahnya perusahaan baru sehingga membuka lapangan pekerjaan bagi masyarakat dan dapat mengurangi angka pengangguran.

2. Pertumbuhan Ekonomi

Akibat adanya aglomerasi industri, berakibat tumbuhnya perekonomian. Pertumbuhan ekonomi yang terjadi diantaranya yaitu, “(a). Meningkatnya kapasitas produksi dan produktivitas, (b). Meningkatnya produksi dikarenakan Meningkatnya infrastruktur, meningkatnya kualitas hidup, dan meningkatnya kualitas SDM yang menetap di daerah aglomerasi, (c). Meningkatnya kapasitas produksi terjadi dikarenakan meningkatnya investasi dan meningkatnya pembelian faktor produksi. Contohnya yaitu mesin serta gedung".

3. Meningkatnya daya Tarik migrasi

Meningkatnya infrastruktur dan meningkatnya kegiatan perekonomian yang terjadi diantaranya yaitu, (a). Bertambahnya lapangan pekerjaan, (b). Upah minimum regional yang relatif lebih tinggi dibandingkan daerah lain menyebabkan masyarakat bermigrasi. Migrasi aglomerasi bisa terjadi dikarenakan meningkatnya kegiatan perekonomian, tumbuhnya usaha-usaha baru membutuhkan para tenaga kerja, dengan adanya migrasi aglomerasi ini tenaga kerja akan lebih tertantang untuk memajukan karirnya.

4. Efisiensi Biaya

Dikarenakan aglomerasi industri terpusat disatu wilayah maka dapat menghemat biaya diantaranya listrik, air, transportasi dan sebagainya.

Disadvantages Aglomerasi Industri yaitu:

1. Polusi (Air, Udara dan Suara)

Terjadinya Aglomerasi industri yang terpusat terhadap aktivitas ekonomi menghasilkan banyaknya polusi udara akibat proses produksi pabrik, polusi udara dari kendaraan, polusi udara dapat menyebabkan hujan asam penyakit pernapasan serta gangguan lainnya, polusi suara dihasilkan dari aktivitas produksi dalam pabrik yang menimbulkan kebisingan sehingga menggangu kenyamanan hidup masyarakat, polusi air terjadi dikarenakan proses pembuangan limbah pabrik ke perairan atau saluran air pembuangan, yang menyebabkan pencemaran polusi air sehingga dapat merusak kehidupan hewan air, dan juga dapat merusak kesehatan bagi masyarakat. 


\section{Kemacetan}

Akibat bertambahnya aktivitas ekonomi terdampak pada aktivitas transportasi baik berupa transortasi barang ataupun transortasi masyarakat itu sendiri.

3. Populasi Penduduk Bertambah

Aglomerasi industri menyebabkan migrasi ke daerah tersebut. dampak buruk yang terjadi jika over populasi diantaranya, (a). Berkurangnya lapangan tenaga kerja. (b), Meningkatnya kemacetan, (c). Kebersihan lingkungan di sekitar lingkungan pemukiman dan lingkungan perkantoran, (d). Meningkatnya angka kriminalitas, (e). Bertambahnya pemukiman kumuh.

4. Alih Fungsi Lahan

Aglomerasi Industri yang berkembang akan menimbulkan economic rent di wilayah tersebut. Yang awalnya lahan pertanian baik sawah maupun kebun dialihfungsikan menjadi daerah industri atau menjadi perumahan, sehingga jika tidak dikelola dengan baik akan menimbulkan akan berdampak pada ekosistem lingkungan.

5. Kesehatan

Aglomerasi industri membuat masyarakat rentan terhadap penyakit, hal tersebut dikarenakan , (a). Terjadinya pembuangan limbah industri, (b). Adanya asap pembakaran industri, (c). Meningkatnya kemacetan. Penyakit yang sering terjadi dialami masyarakat diantaranya penyakit pernapasan, demam, tipes, dan sebagainya.

6. Kerusakan Lingkungan

Aglomerasi industri dapat menyebabkan kerusakan lingkungan dikarenakan aktivitas ekonomi yang pesat dapat menyebabkan polusi dan hilangnya biodiversitas local

Suatu wilayah menjadi sangat penting jika terdapat aglomerasi industri yang terpusat, ini dikarenakan hal tersebut bisa berdampak positif bagi industri dan masyarakat pada daerah itu, Adapun dampak positif itu diantaranya adalah, “(a). Tumbuhnya perekonomian, baik insfrastruktur dan sumber daya manusia, (b). Meningkatnya lapangan pekerjaan bagi masyarakat di daerah aglomerasi". Pentingnya peran serta pemerintah guna mendukung daerah aglomerasi agar bisa bertumbuh dikarenakan masyarakat yang migrasi agar terserap di berbagai sektor industri, dengan memperhatikan kualitas sumber daya manusia. Diharapkan adanya pelatihan-pelatihan sumber daya manusia dari pemerintah dan lembaga swasta dapat meningkatkan kualitas sumber daya manusia agar mampu bersaing dan meningkatkan kualitas hidup masyarakat. Agar pembangunan daerah merata diperlukan industri-industri baru dari berbagai sektor dan fasilitas infrastruktur yang memadai serta dibutuhkannya inovasi dan kreatifitas khususnya dari masyarakat agar mampu meningkatkan kualitas hidup dan meningkatkan daya saing. Wilayah-wilayah di Indonesia yang berpotensi agar dilakukan pemerataan dan adanya keterhubungan banyaknya infrastruktur di berbagai sektor secara meluas dapat meningkatkan pertumbuhan yang lebih baik dibandingkan terpusat, terciptanya Hilirisasi Industri serta dapat melaksanakan penilaian Aglomerasi Industri secara berkala. 


\section{REFERENSI}

Badan Pusat Statistika. 2015-2019. Produk Domestik Regional Bruto. Jakarta, Badan Pusat Statistik

Glaeser, E.L., Kallal, H.D., Scheinkman, J.A. and Shleifer, A. (1992), 'Growth in Cities', Journal of Political Economy, 100, 1126-52.

Sugiyono. 2009. Metode Penelitian Pendidikan. Jakarta: Rajagrafindo Persada.

Sjafrizal. 2014. Ekonomi Wilayah dan Perkotaan. Jakarta: PT. Rajagrafindo Persada.

Wulandari, Y., Lestari, E. K., \& Subagiarta, I. W. (2019). Aglomerasi Industri Pengolahan Di Wilayah Kabupaten Jember Tahun 2011-2015 ( Studi Kasus: Subsektor Industri Makanan, Minuman , dan Tembakau) ( Agglomeration Industries In Jember District Year 2011-2015 (Case Study: Subsector of Food , Beverage and T. VI(1), 76-80.

Putra, M. U. M. (2015). Keuntungan Aglomerasi Kawasan Ekonomi Khusus ( KEK ) Sei Mangkei Terhadap Peningkatan Efisiensi Industri Wilayah Sekitarnya. Human Falah, 2(1), 136-151.

Saleh, B., \& Warlina, L. (2017). Identifikasi Karakteristik Aglomerasi Industri Pengolahan Di Cikarang Kabupaten Bekasi Tahun 2006 Dan 2013. Jurnal Wilayah Dan Kota, 4(01), 37-53. https:/ / doi.org/10.34010/jwk.v4i01.2119

Purbatin, W., \& Soenjoto, P. (2020). ( Studi Kasus 5 Daerah Aglomerasi di Jawa Timur Tabun 2016-2017 ). 1(2), 24-41.

Zuliastri, F., Rindayati, W., \& Asmara, A. (2018). Analisis Faktor Yang Memengaruhi Aglomerasi Industri Unggulan Daerah Dan Hubungannya Dengan Daya Saing Industri Daerah. Jurnal Ekonomi Dan Kebijakan Pembangunan, 2(2), 113-134. https://doi.org/10.29244/jekp.2.2.113-134.

Mulyani, E. (2017). Ekonomi Pembagunan. In Angewandte Chemie International Edition (Vol. 6, Issue 11). 